\title{
Review of Articles Related to Mixed Reality in Education
}

\author{
Mertkan Sinoplu 1 (iD) Fatma Gizem Karaoğlan Yılmaz ${ }^{2}$ \\ ${ }^{1}$ Information Systems and Technologies / Bartın University, Graduate Education Institute, Bartın, Turkey \\ mertkansinoplu@gmail.com \\ ${ }^{2}$ Computer Technology and Information Systems / Bartın University, Faculty of Science, Bartın, Turkey \\ gkaraoglanyilmaz@gmail.com
}

\begin{tabular}{ll}
\hline Article Info & ABSTRACT \\
\hline $\begin{array}{l}\text { Article History } \\
\text { Received: } 10 / 03 / 2021\end{array}$ & $\begin{array}{l}\text { With the development of technology, there have been developments in the field of education as in every } \\
\text { field. Among these developments, it can be said that the most important developments regarding } \\
\text { educational environments are reality technologies. These technologies can be divided into three categories } \\
\text { accepted: } 17 / 06 / 2021\end{array}$ \\
Published: $21 / 06 / 2021$ & $\begin{array}{l}\text { a virtual reality, augmented reality and mixed reality. Since mixed reality, one of these technologies, is } \\
\text { a combination of virtual and augmented reality, it is thought that studies in this field will contribute to } \\
\text { studies in other realities. In this study, the articles using mixed reality technologies were systematically } \\
\text { examined. After the examination, the articles were evaluated and classified according to the criteria } \\
\text { determined. With the study, the distributions of the articles on mixed reality in the field of education } \\
\text { between years 2016-2020 in the Web of Science database were found according to the determined criteria } \\
\text { and inferences were made about these distributions. As a result of the study, it was concluded that most } \\
\text { of the articles were published in 2020 and 2018. In addition to this result, it was determined that } \\
\text { Mixed reality, }\end{array}$ \\
education, & $\begin{array}{l}\text { quantitative articles were much more than qualitative articles. It was seen that experimental-applied study } \\
\text { was mainly chosen as the type of article. Science was found to be the most preferred learning area. It was } \\
\text { reality } \\
\text { environments, } \\
\text { learning } \\
\text { environments. }\end{array}$ \\
$\begin{array}{l}\text { questionnaire was the most chosen data collection tool. Finally, it was concluded that "50-99" and "0-24" } \\
\text { are the most selected sample ranges in mixed reality research in education. }\end{array}$
\end{tabular}

Citation: Sinoplu, M. \& Karaoğlan Yılmaz, F. G. (2021). Review of articles related to mixed reality in education. Journal of Teacher Education and Lifelong Learning, 3(1), 20-31.

"This article is licensed under a Creative Commons Attribution-NonCommercial 4.0 International License (CC BY-NC 4.0)" 


\section{INTRODUCTION}

With the development of technology, different technologies have been developed in the field of education as in every field. It is possible to say that with the increase of different technologies and the methods brought by these technologies in education, the quality and efficiency of education have increased (Mikulecký, 2012). Thanks to these studies carried out in the field of education, the use of different technology fields in the field of education increases and different training methods are developed.

Some of the visual and audio technologies used in education are reality technologies. Reality technologies can be used for different purposes with different technological tools. These technologies can be used as supportive education for distance and regular education. Reality technologies can be examined in 3 areas as virtual reality, augmented reality and mixed reality.

Virtual reality is the human-computer interface that simulates an environment (Zheng et al., 1998). Thanks to virtual reality, users can be in virtual environments created and do things that they normally cannot do. It is possible to say that this system is also widely used for educational studies. As a study on this subject, Huang et al. (2010) examined students' attitudes towards virtual reality environments. While different methods related to virtual reality were examined in the study, the opinions of the participants about these methods were taken. As a result of the study, it was stated that virtual reality learning environments provide a better learning environment with the imagination of individuals.

As another study on virtual reality, Çavaş et al. (2004) provided information about the features of virtual reality technology and how virtual reality technology can be used in education. In the study, they talked about the advantages, disadvantages and usage areas of different virtual reality devices and environments. They also mentioned in which educational fields these technologies can be used appropriately. In the study, they explained the use of these technologies in the education of special education, architecture, history, science and mathematics, medicine, military and airline fields. As a result, it was stated that using virtual technologies in the field of education would significantly increase students' motivation and attitudes.

The opinions of the teacher candidates about the use of virtual reality in education are as important as the opinions of the students. Karaoğlan Y1lmaz and Y1lmaz (2019) examined the opinions of preservice teachers about the use of virtual reality applications in education. They stated in the study that virtual reality technology can be preferred in fields such as science and technology, medical education and engineering. As a result of interviews with 15 pre-service teachers, it was stated that virtual reality technologies have effects such as making the learning environment enjoyable and increasing creative thinking and motivation. In addition, it was stated that some participants experienced dizziness and nausea while using this technology, and this problem may cause problems in terms of classroom management.

Another reality technology is augmented reality. Augmented reality is realized by placing 3D objects in 3D environments in real time (Azuma, 1997). The difference of this technology from virtual reality is that the real and virtual environment can be used together. This technology is frequently used in educational studies as well as in virtual reality. As a study on this technology, Wu et al. (2013) evaluated the point reached by augmented reality in the field of education and the opportunities in this field. In addition, they gave information about how augmented reality can be used for different education fields.

As another study on augmented reality, Durak and Karaoğlan Y1lmaz (2019) examined the opinions of secondary school students about augmented reality educational applications of augmented reality. Secondary school students' opinions about this technology were taken and they stated the positive and negative aspects of this technology. As a result of the examination of students' opinions, it was stated that 
the difference of augmented reality applications compared to traditional education was "to provide a fun educational environment and to make the learning process effective". In addition, it was stated from the students that the biggest problem in using this technology was "access to smart phones". The field of "science" was specified as education in which this technology could be most beneficial.

The last of the reality technologies is mixed reality. It is a technology that includes the concepts of mixed reality, virtual reality and augmented reality. Mixed reality is created by using real images and sounds supported by virtual images and sounds (Billinghurst \& Kato, 1999). In this technology, virtual objects created in real environments can be viewed and interacted with.

Mixed reality technology is used in many different areas. One of these areas is museum and historical places. As a study on this field, Diker (2019) focused on the examination of the Troy museum with mixed reality technology in his study. In the study, museums from different parts of the world were examined and compared. In addition, the methods of using mixed reality technology in museums have been researched. As a result of the study, it was stated that the Troy Museum was in a structure suitable for mixed reality.

One of the most used fields of mixed education is the field of medical education. As a study on this subject, Birt et al. (2018) focused on the use of mobile mixed reality technologies in health and medicine. In the study, the opinions of higher education students about mixed reality technologies were taken. In addition, different mixed reality technologies have been evaluated. As a result of the study, it was stated that some users find mixed reality technology to be too complex, but it is more useful than traditional education in areas such as surface anatomy.

The aim of the study is to examine the studies related to mixed reality in the field of education and to make a systematic analysis for future studies in this field. With the study, it was aimed to determine the areas where mixed reality technologies can be used in education and the places where the usage methods are intense and sparse, and to learn from these results. While examining the articles about mixed reality and education in the study, answers to the following questions were sought:

1. What is the distribution of articles on mixed reality by years?

2. How is the distribution of articles on mixed reality according to article methods?

3. What is the distribution of articles on mixed reality according to article types?

4. How is the distribution of articles on mixed reality according to learning areas?

5. What is the distribution of articles on mixed reality according to sample levels?

6. What is the distribution of articles on mixed reality according to the number of samples?

7. How is the distribution of articles on mixed reality according to data collection tools?

\section{METHOD}

In the study, descriptive survey model was used to examine the articles. As a feature of this model, the reason for using this model can be given as the reason for the use of this model is to consider appropriate articles for generalizability of the results (Büyüköztürk, Çakmak, Akgün, Karadeniz, \& Demirel, 2017). 


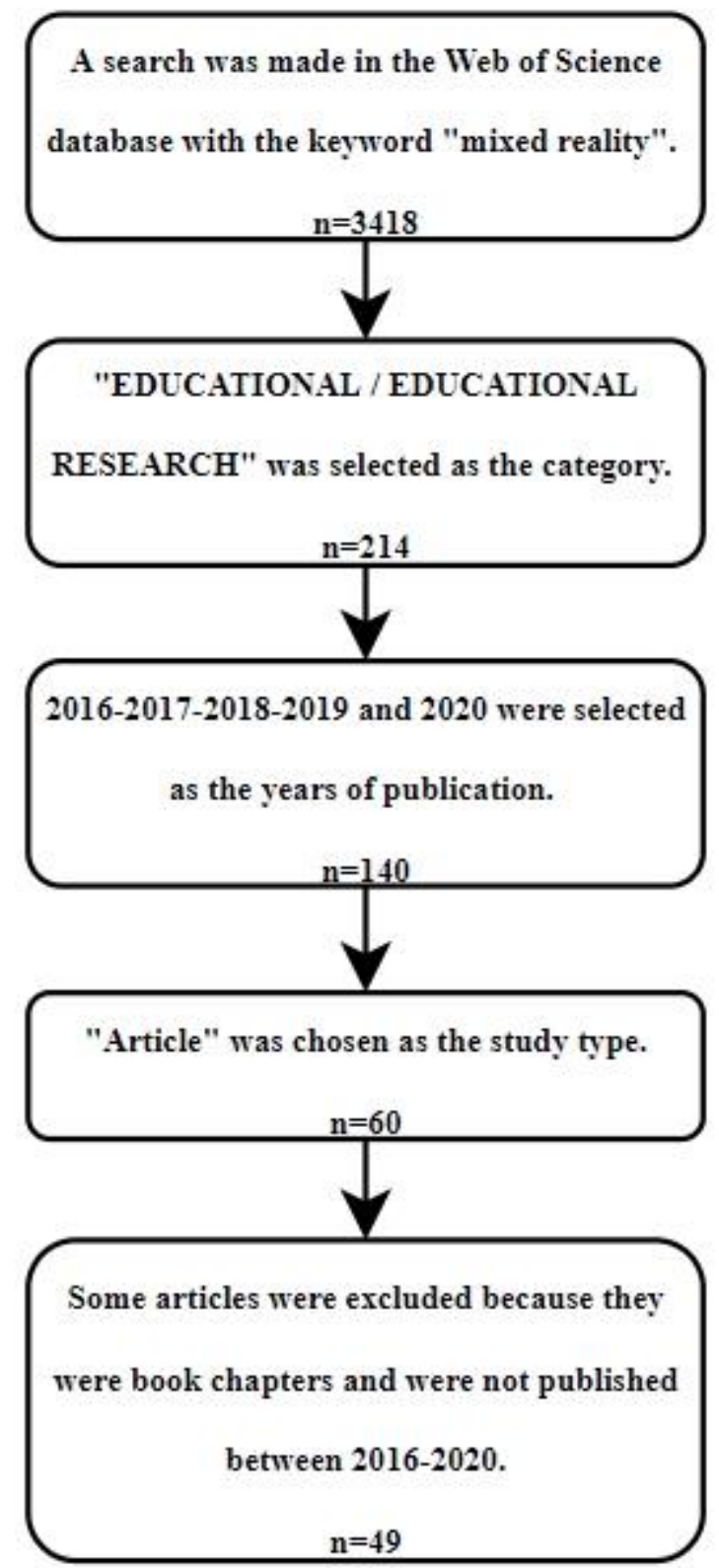

Figure 1. Article selection process

The criteria used in the selection stages of the articles are given in Figure 1. In the study, a search was made on Web of Science with "mixed reality". The search made is limited to the years 2016-20172018-2019 and 2020. Later, "EDUCATION / EDUCATIONAL RESEARCH" category was selected as the category. Finally, only the articles among the studies were discussed. 60 articles were found as a result of the search. As a result of the examinations, 8 articles were excluded because there are book chapters, 3 articles excluded because of open accessed in 2020 but published in 2021. After exclusions, study continued with 49 articles.

The articles were analyzed in computer environment. An article review form was created to analyze the data. In this form, criteria such as article type, article method, learning areas, sample number and level, data collection tools and article years were determined. Form 3 was created by taking the opinion of the field expert and the form was finalized.

The 49 articles obtained after the filtering were evaluated according to the criteria determined in the examination form. 


\section{FINDINGS}

The findings related to the article were examined under the headings according to the answers to the questions sought as the aim of the study. Percentage values of the examined articles are given as two digits after the comma. The findings were determined by the year (Figure 2), article methods (Figure 3), article types (Figure 4), learning domains (Figure 5), sample levels (Figure 6), and sample numbers (Figure 6), respectively. Figure 7) and according to data collection tools (Figure 8).

\section{1- Distribution of articles on mixed reality by years}

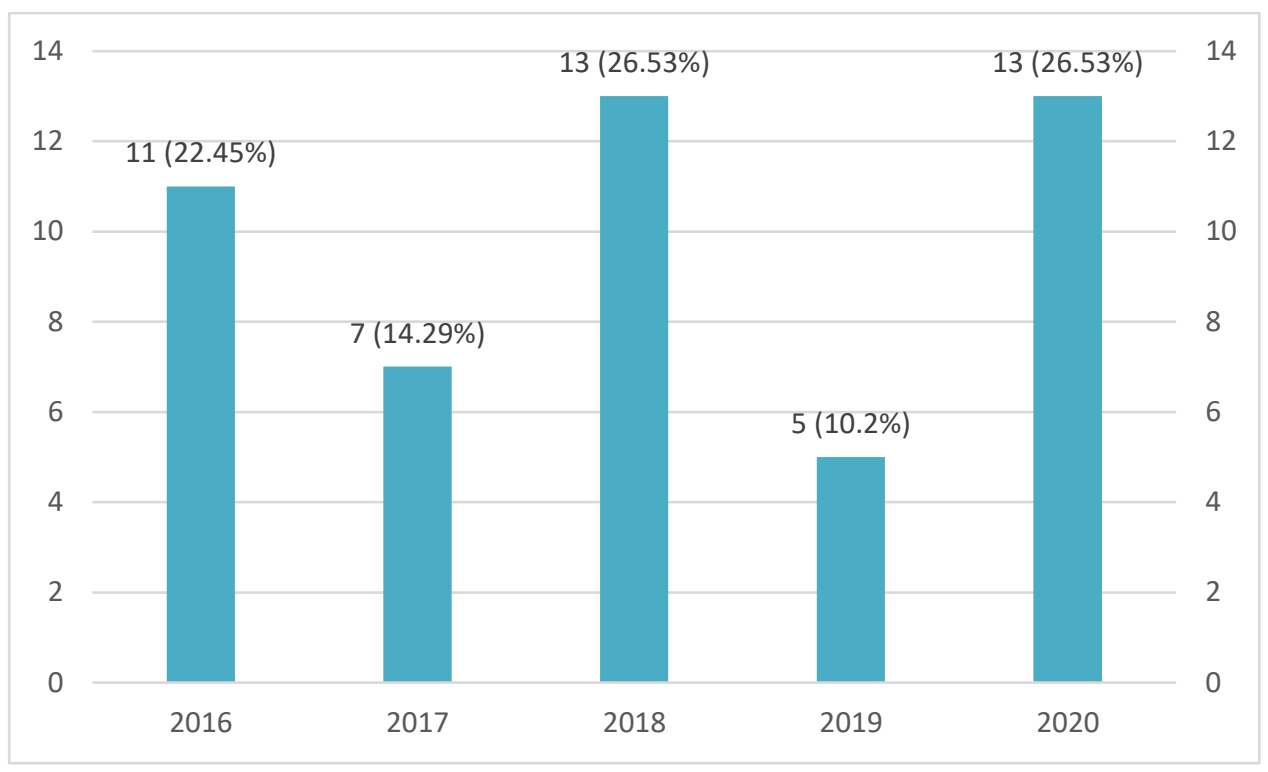

Figure 2. Distribution of articles on mixed reality by years

The distribution of the examined articles by years is shown in Figure 2. The articles were reviewed on a 5-year basis as 2020, 2019, 2018, 2017 and 2016. It was seen that the year in which the most studies were conducted on mixed reality was 2018 and 2020 (26.53\%) with 13 studies. 2018 and 2020 are followed by 2016 (22.45\%) with 11 articles, 2017 (14.29\%) with 7 articles and 2019 (10.2\%) with 5 articles.

\section{2- Distribution of articles on mixed reality by article methods}

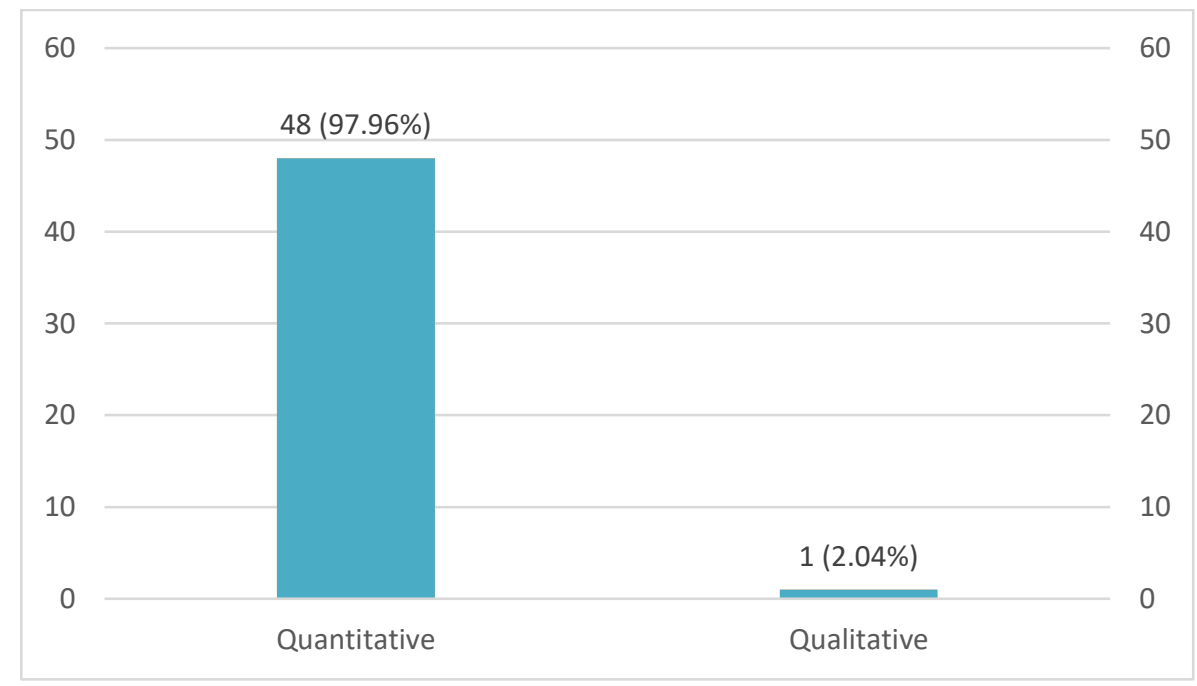

Figure 3. Distribution of articles on mixed reality by article methods 
The distribution of the examined articles according to the article methods is shown in Figure 3. Articles were evaluated in two groups as quantitative and qualitative. It was seen that the most used method in studies on mixed reality was quantitative method with 48 articles (97.96\%). It was found that there was only 1 article using the qualitative method (2.04\%).

\section{3- Distribution of articles on mixed reality by article types}

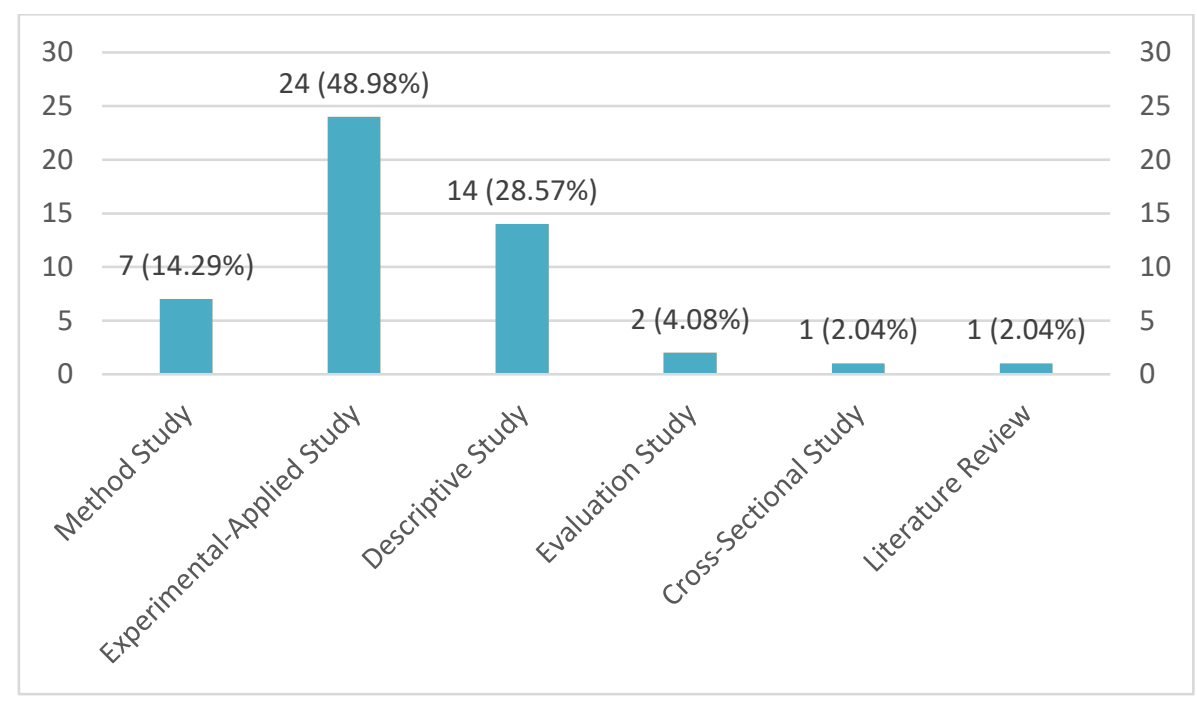

Figure 4. Distribution of articles on mixed reality by article types

The distribution of the examined articles by article types is shown in Figure 4. The articles were examined in 6 types as method study, experimental-applied study, descriptive study, evaluation study, cross-sectional study and literature review study. Considering the types of his studies on mixed reality, it is seen that the most preferred article type is experimental-applied study with 24 articles (48.98\%). The experimental-applied study type is followed by descriptive study with 14 articles $(28.57 \%)$, method study with 7 articles (14.29\%), evaluation study with 2 articles $(4.08 \%)$, and cross-sectional and literature review studies with one article (2.04\%). According to the results, it can be said that descriptive and experimental-applied studies are in majority.

\section{4- Distribution of articles on mixed reality according to learning areas}

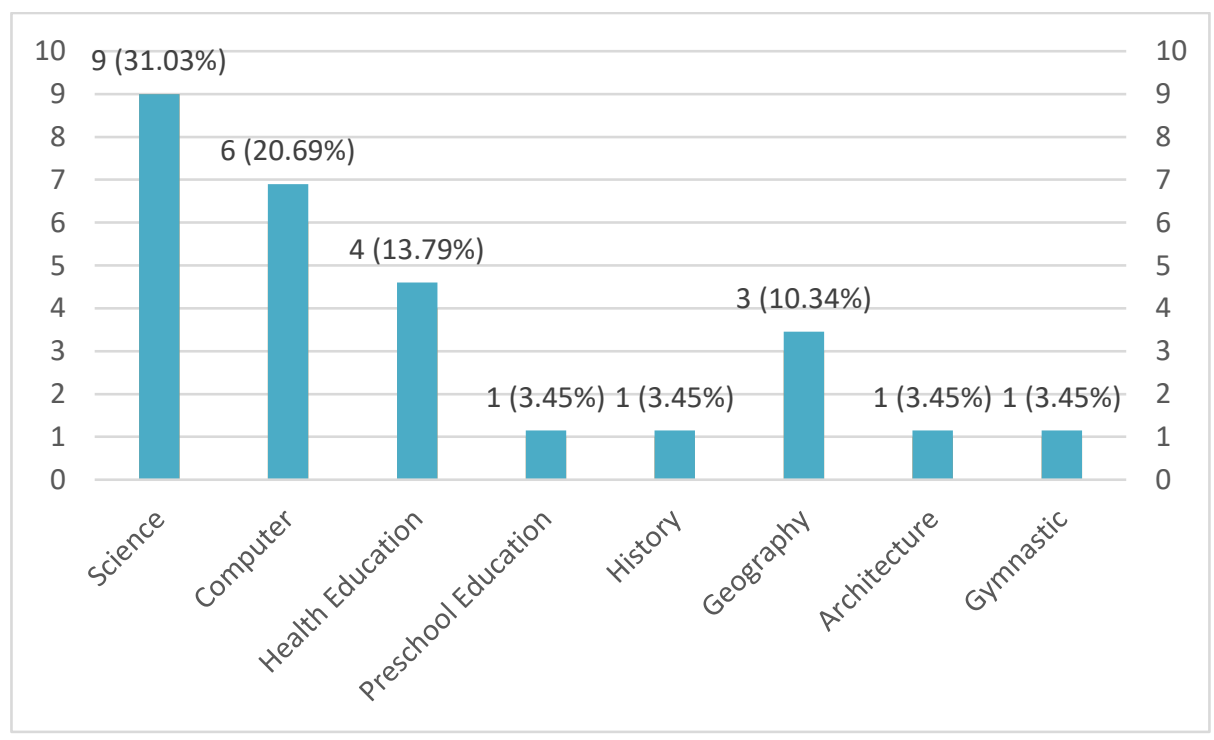

Figure 5. Distribution of articles on mixed reality according to learning areas 
The distribution of the examined articles according to learning areas is shown in Figure 5. When the learning areas of his studies on mixed reality were examined, it was seen that the most studies were in the field of science with 9 articles $(31.03 \%)$. The field of science was followed by computers with 6 articles (20.69\%), health education with 4 articles (13.79\%), geography with 3 articles (10.34\%) and history, architecture, preschool education and gymnastics with 1 article (3.45\%).

\section{5- Distribution of articles on mixed reality by sample levels}

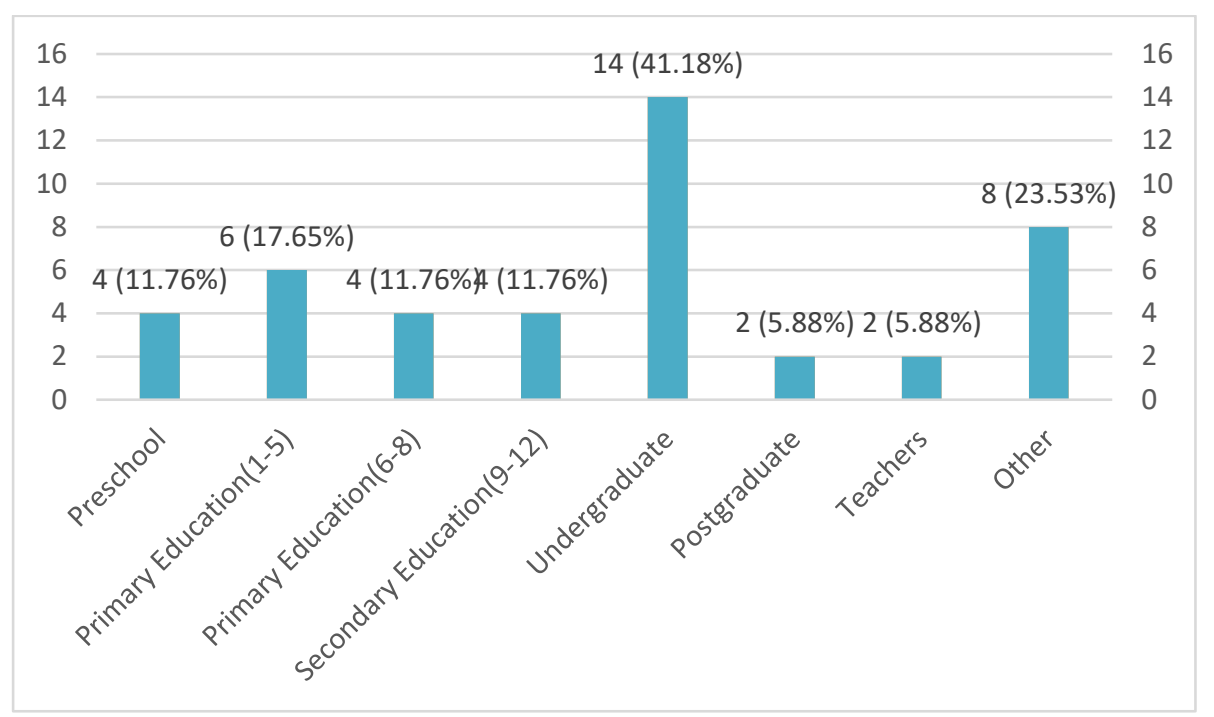

Figure 6. Distribution of articles on mixed reality by sample levels

The distribution of the examined articles according to the sample levels is shown in Figure 6 . The articles were evaluated at 8 levels: pre-school, primary education (1-5), primary education (6-8), secondary education (9-12), undergraduate, graduate, teachers and other. When we look at the sample levels in the studies on mixed reality, the undergraduate sample level $(41.18 \%)$ comes with 14 articles at the most. 8 articles with other sample level (23.53\%), 6 articles with primary education (1-5) sample level (17.65\%), 4 articles with primary education (6-8), secondary education (9-12) and preschool sample level $(11.76 \%), 2$ articles with postgraduate and teachers sampling level (5.58\%), follow the undergraduate sampling level.

\section{6- Distribution of articles on mixed reality by sample numbers}

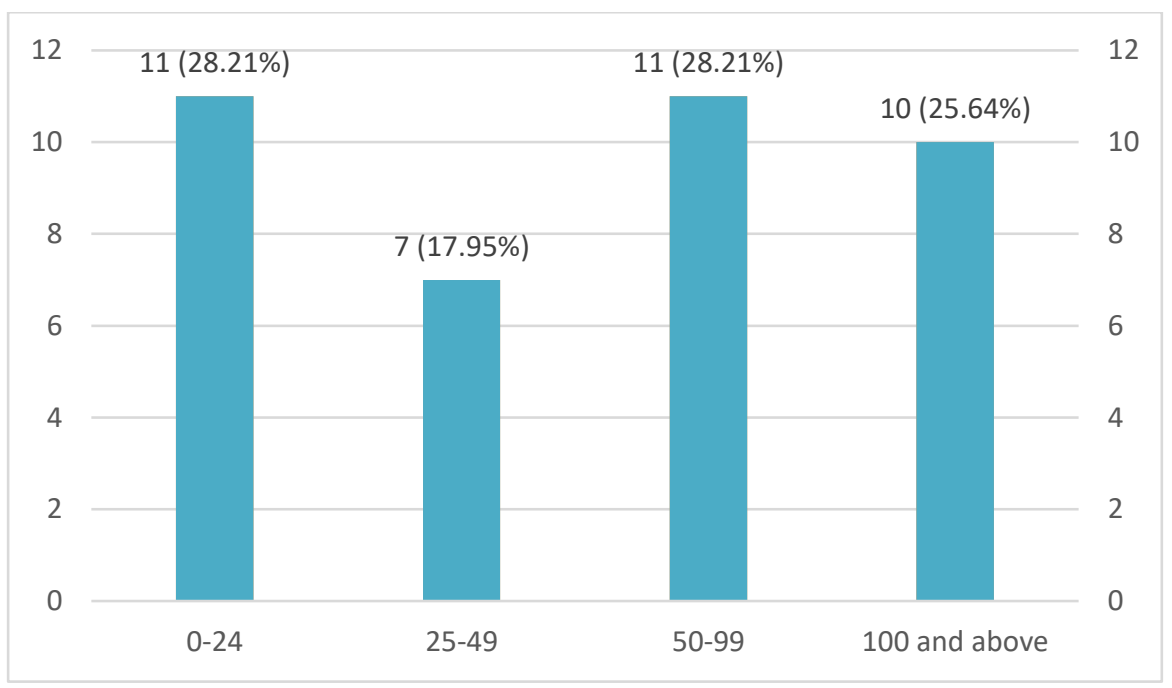

Figure 7. Distribution of articles on mixed reality by sample numbers 
The distribution of the examined articles according to the sample numbers is shown in Figure 7. Articles were evaluated in 4 ranges as "0-24", "25-49", "50-99" and "100 and above". In studies on mixed reality, "0-24" and "50-99" sample range (28.21\%) was used mostly with 11 articles. "0-24" and "50-99" sample range was followed by 10 articles with "100 and above" sample level (25.64\%) and 7 articles with “25-49” sample level (17.95\%).

\section{7- Distribution of articles on mixed reality according to data collection tools}

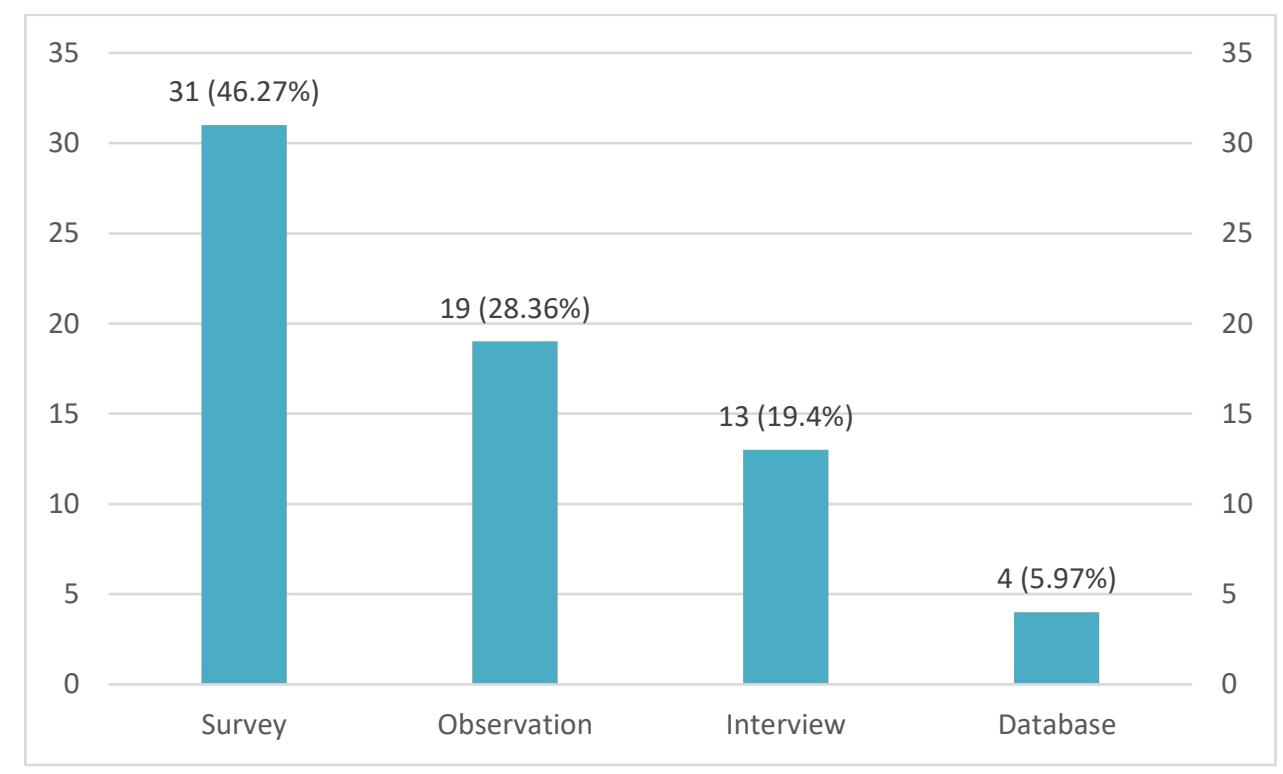

Figure 8. Distribution of articles on mixed reality according to data collection tools

The distribution of the examined articles according to the data collection tools is shown in Figure 8. The articles were evaluated in terms of four data collection tools: survey, observation, interview and database. Questionnaire with 31 articles (46.27\%) is the most used data collection tool in studies on mixed reality. The survey is followed by observation with 19 articles (28.36\%), interview with 13 articles $(19.4 \%)$ and database with 4 articles (5.97\%). According to these results, it can be said that the user survey was used in most of the studies.

\section{CONCLUSION AND RECOMMENDATIONS}

The analysis of the articles on mixed reality in the field of education has been made with the study. With the analysis, an evaluation was made according to years, article types, article methods, sample levels, sample sizes, learning areas and data collection tools. It is thought that the evaluation will help researchers who will work on these issues in the future.

In the section where the articles are examined by years, it can be interpreted that less articles were produced in 2019 on mixed reality in the field of education than in 2018 and 2020, this issue did not develop or its development slowed down in 2019. Considering this result, it is possible to say that future studies in this field will have a very important role for the field. Considering the number of articles by years, the increase and decrease in the numbers are not continuous. As a supportive study of this result, when the study of İçten and Güngör (2017) on augmented reality technology was examined, no regular increase or decrease was observed in the number of studies over the years.

When the articles were examined according to article methods, it was seen that the most used method was the quantitative methods (97.96\%). Considering this value, it can be stated that most of the studies on the subject use a quantitative methods and focus on the research of the current situation in a 
subject. In addition, since the qualitative methods (2.04\%) is used very little, it can be predicted that a study to be done with this method in the future can advance mixed reality studies in education.

When the articles were examined according to article types, it was seen that the most used type was experimental-applied work (48.98\%). In addition, it was seen that the descriptive study (28.57\%) was used in a number of articles close to the experimental-applied study type. Considering these results, it is seen that most of the studies on the subject focus on three types: experimental-applied, method and descriptive work. In the evaluation, it is thought that the articles to be made with these types of studies in the future may be important in terms of the study type due to the low use of cross-sectional study (2.04\%), literature review study $(2.04 \%)$ and evaluation $4.08 \%)$.

With the evaluation of the articles according to their learning areas, it was determined that the majority of the articles were made in the field of science $(31.03 \%)$. Computer $(20.69 \%)$ and health education (13.79\%) follow this area. Considering these results, it can be said that mixed reality technologies are frequently used in educational studies in the field of science. In addition, in the examination made according to the learning areas, there were gatherings in three areas intensively. Looking at this result, it can be predicted that future studies on mixed reality in different learning areas will potentially be pioneering studies in their fields. In the studies of Tekdal and Sayginer (2016), where they analyzed the studies in which augmented reality was used in the field of education, it was stated that the field of physics was the most preferred field for application. As a result, the results of the two studies on the learning area overlap with each other.

As a result of the study on the sample levels used in the articles, it was determined that the most used sample level was undergraduate (41.18\%). The high number of samples (23.53\%) outside the sample levels determined in the study revealed that the studies on this subject were conducted with participants from different levels. In Özdemir's (2017) study on this subject, it was stated that secondary school students were selected at the highest sampling level in studies on augmented reality. Considering this result, it can be said that different sampling levels are frequently preferred in studies on different reality technologies.

As a result of the study on the sample numbers of the articles, it was seen that the sampling range of "0-25" and "50-99" was used the most. Based on this result, it can be said that studies conducted with mixed reality are conducted with a relatively small sample. In a study that supports this result, Usta et al. (2017) examined the studies on augmented reality, and it was stated that 22 out of 33 articles in total used samples in the range of "1-10" and "11-30" as the sample size range. Considering this result, it can be said that relatively few samples are preferred in different realities.

One of the limitations of this study can be given as only the search for articles in the Web of Science database. In future studies, other databases may be included in the research. Since this research was conducted in 2021 and there may be other studies on this subject in 2021, studies in 2021 were not included in the study. For studies after 2021, it can be suggested that the articles in 2021 should be added to the research. As a suggestion for future studies on this subject, adding the environments using mixed reality devices as a category can be given. In this way, it can be determined whether mixed reality devices are preferred more in mobile or computer environment in terms of education. 


\section{REFERENCES}

Azuma, R. T. (1997). A survey of augmented reality. Presence: Teleoperators \& Virtual Environments, 6(4), $355-385$.

Billinghurst, M., \& Kato, H. (1999, March). Collaborative mixed reality. In Proceedings of the First International Symposium on Mixed Reality (pp. 261-284).

Birt, J., Stromberga, Z., Cowling, M., \& Moro, C. (2018). Mobile mixed reality for experiential learning and simulation in medical and health sciences education. Information, 9(2), 31.

Büyüköztürk, Ş., Çakmak, E. K., Akgün, Ö. E., Karadeniz, Ş., \& Demirel, F. (2017). Bilimsel araştırma yöntemleri (23. Baskı). Ankara: Pegem Akademi Yayıncılık.

Çavas, B., Çavas, P. H., \& Can, B. T. (2004). Egitimde sanal gerceklik. TOJET: The Turkish Online Journal of Educational Technology, 3(4).

Diker, O. Karma Gerçeklikli Görsel Müze Olarak Troya Müzesinin Karma Görsellik Yöntemi ile İncelenmesi. Gastroia: Journal of Gastronomy and Travel Research, 3(1), 197-224.

Durak, A., \& Karaoğlan Yılmaz, F. G. K. (2019). Artırılmiş gerçekliğin eğitsel uygulamalari üzerine ortaokul öğrencilerinin görüşleri. Abant İzzet Baysal Üniversitesi Eğitim Fakültesi Dergisi, 19(2), 468-481.

Huang, H. M., Rauch, U., \& Liaw, S. S. (2010). Investigating learners' attitudes toward virtual reality learning environments: Based on a constructivist approach. Computers \& Education, 55(3), 1171-1182.

İçten, T., \& Güngör, B. A. L. (2017). Artırılmış gerçeklik teknolojisi üzerine yapılan akademik çalışmaların içerik analizi. Bilişim Teknolojileri Dergisi, 10(4), 401-415.

Karaoğlan Yılmaz, F. G., \& Yılmaz, R. (2019). Sanal gerçeklik uygulamalarının eğitimde kullanımına ilişkin öğretmen adaylarının görüşlerinin incelenmesi.

Mikulecký, P. (2012, April). Smart environments for smart learning. In DIVAI 2012 9th International Scientific Conference on Distance Learning in Applied Informatics (pp. 213-222).

Özdemir, M. (2017). Artırılmış gerçeklik teknolojisi ile öğrenmeye yönelik deneysel çalışmalar: sistematik bir inceleme. Mersin Üniversitesi Eğitim Fakültesi Dergisi, 13(2), 609-632.

Usta, E., Korucu, A. T., \& Yavuzarslan, İ. F. (2016). Eğitimde artırılmış gerçeklik teknolojilerinin kullanımı: 2007-2016 döneminde Türkiye'de yapılan araştırmaların içerik analizi. Alan Eğitimi Araştırmaları Dergisi, 2(2), 84-95.

Zheng, J. M., Chan, K. W., \& Gibson, I. (1998). Virtual reality. IEEE Potentials, 17(2), 20-23.

Wu, H. K., Lee, S. W. Y., Chang, H. Y., \& Liang, J. C. (2013). Current status, opportunities and challenges of augmented reality in education. Computers \& Education, 62, 41-49.

\section{APPENDIX 1- ARTICLES EXAMINED IN STUDY}

Aguayo, C., Dañobeitia, C., Cochrane, T., Aiello, S., Cook, S., \& Cuevas, A. (2018). Embodied reports in paramedicine mixed reality learning. Research in Learning Technology, 26.

Aguayo, C., Eames, C., \& Cochrane, T. (2020). A Framework for Mixed Reality Free-Choice, Self-Determined Learning. Research in Learning Technology, 28.

Ali, A. A., Dafoulas, G. A., \& Augusto, J. C. (2019). Collaborative educational environments incorporating mixed reality technologies: A systematic mapping study. IEEE Transactions on Learning Technologies, 12(3), 321-332.

Beyoglu, D., Hursen, C., \& Nasiboglu, A. (2020). Use of mixed reality applications in teaching of science. Education and Information Technologies, 25(5), 4271-4286.

Birt, J., \& Cowling, M. (2018). Assessing mobile mixed reality affordances as a comparative visualization pedagogy for design communication. Research in Learning Technology, 26, 1-25.

Birt, J., Moore, E., \& Cowling, M. (2017). Improving paramedic distance education through mobile mixed reality simulation. Australasian Journal of Educational Technology, 33(6).

Burleson, W. S., Harlow, D. B., Nilsen, K. J., Perlin, K., Freed, N., Jensen, C. N., ... \& Muldner, K. (2017). Active learning environments with robotic tangibles: Children's physical and virtual spatial programming experiences. IEEE Transactions on Learning Technologies, 11(1), 96-106.

Chao, J., Chiu, J. L., DeJaegher, C. J., \& Pan, E. A. (2016). Sensor-augmented virtual labs: Using physical interactions with science simulations to promote understanding of gas behavior. Journal of Science Education and Technology, 25(1), 16-33.

Chen, C. H., Chou, Y. Y., \& Huang, C. Y. (2016). An augmented-reality-based concept map to support mobile learning for science. The Asia-Pacific Education Researcher, 25(4), 567-578.

Chew, E. and Chua, X.N. (2020), Robotic Chinese language tutor: personalising progress assessment and feedback or taking over your job?., On the Horizon, Vol. 28 No. 3, pp. 113-124.

Chini, J. J., Straub, C. L., \& Thomas, K. H. (2016). Learning from avatars: Learning assistants practice physics pedagogy 
in a classroom simulator. Physical Review Physics Education Research, 12(1), 010117.

Cochrane, T., Aiello, S., Cook, S., Aguayo, C., \& Wilkinson, N. (2020). MESH360: a framework for designing MMRenhanced clinical simulations. Research in Learning Technology, 28.

Cochrane, T., Stretton, T., Aiello, S., Britnell, S., Cook, S., \& Naryan, V. (2018). Authentic interprofessional health education scenarios using mobile VR. Research in Learning Technology, 26.

Cohen, J., Wong, V., Krishnamachari, A., \& Berlin, R. (2020). Teacher coaching in a simulated environment. Educational Evaluation and Policy Analysis, 42(2), 208-231.

Dalinger, T., Thomas, K. B., Stansberry, S., \& Xiu, Y. (2020). A mixed reality simulation offers strategic practice for pre-service teachers. Computers \& Education, 144, 103696.

Danish, J. A., Enyedy, N., Saleh, A., \& Humburg, M. (2020). Learning in embodied activity framework: a sociocultural framework for embodied cognition. International Journal of Computer-Supported Collaborative Learning, 15, 49-87.

Dawson, M. R., \& Lignugaris/Kraft, B. (2017). Meaningful practice: Generalizing foundation teaching skills from TLE TeachLivE ${ }^{\mathrm{TM}}$ to the classroom. Teacher Education and Special Education, 40(1), 26-50.

Essmiller, K., Asino, T. I., Ibukun, A., Alvarado-Albertorio, F., Chaivisit, S., Do, T., \& Kim, Y. (2020). Exploring mixed reality based on self-efficacy and motivation of users. Research in Learning Technology, 28.

Frank, J. A., \& Kapila, V. (2017). Mixed-reality learning environments: Integrating mobile interfaces with laboratory test-beds. Computers \& Education, 110, 88-104.

Gallagher, S. (2018). Educating the right stuff: Lessons in enactivist learning. Educational Theory, 68(6), 625-641.

Gautam, A., Williams, D., Terry, K., Robinson, K., \& Newbill, P. (2018). Mirror worlds: examining the affordances of a next generation immersive learning environment. TechTrends, 62(1), 119-125.

Huang, H. M., \& Liaw, S. S. (2018). An analysis of learners' intentions toward virtual reality learning based on constructivist and technology acceptance approaches. International Review of Research in Open and Distributed Learning, 19(1).

Kalpakis, S., Palaigeorgiou, G., \& Kasvikis, K. (2018). Promoting Historical Thinking in Schools through Low Fidelity, Low-Cost, Easily Reproduceable, Tangible and Embodied Interactions. International Journal of Emerging Technologies in Learning, 13(12).

Katzis, K., Dimopoulos, C., Meletiou-Mavrotheris, M., \& Lasica, I. E. (2018). Engineering attractiveness in the European educational environment: Can distance education approaches make a difference?. Education Sciences, 8(1), 16.

Keifert, D., Lee, C., Enyedy, N., Dahn, M., Lindberg, L., \& Danish, J. (2020). Tracing bodies through liminal blends in a mixed reality learning environment. International Journal of Science Education, 1-23.

Langbeheim, E., \& Levy, S. T. (2018). Feeling the forces within materials: bringing inter-molecular bonding to the fore using embodied modelling. International Journal of Science Education, 40(13), 1567-1586.

Ledger, S., \& Fischetti, J. (2020). Micro-teaching 2.0: Technology as the classroom. Australasian Journal of Educational Technology, 36(1), 37-54.

Lee, H., Parsons, D., Kwon, G., Kim, J., Petrova, K., Jeong, E., \& Ryu, H. (2016). Cooperation begins: Encouraging critical thinking skills through cooperative reciprocity using a mobile learning game. Computers \& Education, 97, 97115.

Leonard, S. N., \& Fitzgerald, R. N. (2018). Holographic learning: A mixed reality trial of Microsoft HoloLens in an Australian secondary school. Research in Learning Technology, 26.

Lindgren, R., Tscholl, M., Wang, S., \& Johnson, E. (2016). Enhancing learning and engagement through embodied interaction within a mixed reality simulation. Computers \& Education, 95, 174-187.

Marcel, F. (2019). Mobile augmented reality learning objects in higher education. Research in Learning Technology, 27.

Murphy, K. M. (2019). Working with Avatars and High Schoolers to Teach Qualitative Methods to Undergraduates. LEARNing Landscapes, 12(1), 183-203.

Oh, S., So, H. J., \& Gaydos, M. (2017). Hybrid augmented reality for participatory learning: The hidden efficacy of multiuser game-based simulation. IEEE Transactions on Learning Technologies, 11(1), 115-127.

Palaigeorgiou, G., Karakostas, A., \& Skenteridou, K. (2018). Touching and traveling on 3D augmented tangible maps for learning geography: The FingerTrips approach. Interactive Technology and Smart Education.

Potkonjak, V., Gardner, M., Callaghan, V., Mattila, P., Guetl, C., Petrović, V. M., \& Jovanović, K. (2016). Virtual laboratories for education in science, technology, and engineering: A review. Computers \& Education, 95, $309-327$.

Roberts, J., \& Lyons, L. (2017). The value of learning talk: applying a novel dialogue scoring method to inform interaction design in an open-ended, embodied museum exhibit. International Journal of Computer-Supported Collaborative Learning, 12(4), 343-376.

Schoeb, D. S., Schwarz, J., Hein, S., Schlager, D., Pohlmann, P. F., Frankenschmidt, A., \& Miernik, A. (2020). Mixed reality for teaching catheter placement to medical students: a randomized single-blinded, prospective trial. BMC medical education, 20(1), 1-8. 
Shakirova, N., Said, N., \& Konyushenko, S. (2020). The Use of Virtual Reality in Geo-Education. International Journal of Emerging Technologies in Learning (iJET), 15(20), 59-70.

Sinfield, D. (2018). The Boundaries of Education: Using mobile devices for connecting people to places. ALTJAssociation for Learning Technology Journal, 26.

Spencer, S., Drescher, T., Sears, J., Scruggs, A. F., \& Schreffler, J. (2019). Comparing the efficacy of virtual simulation to traditional classroom role-play. Journal of Educational Computing Research, 57(7), 1772-1785.

Stefan, L., Moldoveanu, F., \& Gheorghiu, D. (2016). Evaluating a mixed-reality 3D virtual campus with big data and learning analytics: A transversal study. Journal of e-Learning and Knowledge Society, 12(2).

Taçgın, Z., \& Arslan, A. (2017). The perceptions of CEIT postgraduate students regarding reality concepts: Augmented, virtual, mixed and mirror reality. Education and Information Technologies, 22(3), 1179-1194.

Tscholl, M., \& Lindgren, R. (2016). Designing for learning conversations: How parents support children's science learning within an immersive simulation. Science Education, 100(5), 877-902.

Vasilevski, N., \& Birt, J. (2020). Analysing construction student experiences of mobile mixed reality enhanced learning in virtual and augmented reality environments. Research in Learning Technology, 28.

Vince Garland, K. M., Holden, K., \& Garland, D. P. (2016). Individualized clinical coaching in the TLE TeachLivE lab: Enhancing fidelity of implementation of system of least prompts among novice teachers of students with autism. Teacher Education and Special Education, 39(1), 47-59.

Walker, Z., Vasquez, E., \& Wienke, W. (2016). The impact of simulated interviews for individuals with intellectual disability. Journal of Educational Technology \& Society, 19(1), 76-88.

Watson, P., \& Livingstone, D. (2018). Using mixed reality displays for observational learning of motor skills: A design research approach enhancing memory recall and usability. Research in Learning Technology, 26.

Weng, C., Rathinasabapathi, A., Weng, A., \& Zagita, C. (2019). Mixed reality in science education as a learning support: a revitalized science book. Journal of Educational Computing Research, 57(3), 777-807.

Zhou, Y. (2016). Application of Automatic Choreography Software Based on Virtual Technology in the Gymnastics Teaching. International Journal of Emerging Technologies in Learning, 11(5). 